\title{
Hormonal Regulation of Glutamate Receptor Gene Expression in the Anteroventral Periventricular Nucleus of the Hypothalamus
}

\author{
Guibao Gu, ${ }^{1}$ Frederique Varoqueaux, ${ }^{1}$ and Richard B. Simerly ${ }^{1,2}$ \\ ${ }^{1}$ Division of Neuroscience, Oregon Regional Primate Research Center, Beaverton, Oregon 97006, and 2Program in \\ Neuroscience, Oregon Health Sciences University, Portland, Oregon 97201
}

\begin{abstract}
Glutamate plays an important role in mediating the positive feedback effects of ovarian steroids on gonadotropin secretion, and the preoptic region of the hypothalamus is a likely site of action of glutamate. The anteroventral periventricular nucleus (AVPV) of the preoptic region is an essential part of neural pathways mediating hormonal feedback on gonadotropin secretion, and it appears to provide direct inputs to gonadotropin releasing hormone (GnRH)-containing neurons. Immunohistochemistry and in situ hybridization were used in this study to define the distribution and hormonal regulation of glutamate receptor subtypes in the AVPV of juvenile female rats. Neurons that express the NMDAR1 receptor subtype are abundant in the AVPV, as are cells that express AMPA receptor subtypes (GluR1, GluR2, and GluR3 but not GluR4), and the AVPV appears to contain a dense plexus of NMDAR1-immunoreactive presynaptic terminals. However, AVPV neurons do not seem to
\end{abstract}

express detectable levels of kainate receptor (GluR5, GluR6, and GluR7) or metabotropic receptor (mGluR1-6) subtypes. Treatment of ovariectomized juvenile rats with estradiol induced expression of GluR1 mRNA but did not alter levels of GluR2 or GluR3 mRNA. Treatment of estrogen-primed ovariectomized juvenile rats with progesterone caused an initial increase in GluR1 mRNA expression, followed by a small decrease $24 \mathrm{hr}$ after treatment. In contrast, estrogen appears to suppress levels of NMDAR1 mRNA in the AVPV, which remained unchanged after progesterone treatment. Thus, one mechanism whereby ovarian steroids may provide positive feedback to $\mathrm{GnRH}$ neurons is by altering the sensitivity of AVPV neurons to glutamatergic activation.

Key words: preoptic region; gonadotropin releasing hormone; in situ hybridization; ovarian steroids; progesterone; estrogen
In both developing and mature mammals, the preovulatory surge in luteinizing hormone ( $\mathrm{LH})$ secretion is dependent on the activation of gonadotropin releasing hormone $(\mathrm{GnRH})$-containing neurons in the preoptic region by estradiol and/or progesterone, because these cells represent the final common pathway for the neural control of ovulation (Gerall and Givon, 1992; Ojeda and Urbanski, 1994). In the rat, GnRH neurons do not appear to express estrogen or progesterone receptors (Shivers et al., 1983; Fox et al., 1990), suggesting that these cells do not transduce the positive feedback effects of ovarian steroids directly. However, it has been known for some time that a neural signal originating from the preoptic area of the hypothalamus is required for the preovulatory LH surge (Halasz, 1969; Köves and Halász, 1970), and an emerging body of evidence suggests that the anteroventral periventricular nucleus (AVPV) in this area, which contains a high density of neurons expressing estrogen and progesterone receptors, plays a pivotal role in mediating the positive feedback effect of ovarian steroids on gonadotropin secretion (Wiegand and Terasawa, 1982; Simerly, 1996; Herbison, 1998). Consistent with its proposed functional role, the AVPV provides direct projections to a subpopulation of GnRH neurons in the vascular

Received Sept. 22, 1998; revised Dec. 1, 1998; accepted Feb. 2, 1999.

This work was supported by National Institutes of Health Grants NS26723, RR00163, and HD18185. We thank Dr. D. Hess for steroid hormone assays, Drs. S. Heinemann and S. Nakanishi for providing plasmids, Dr. C. Meshul for the use of electron microscope, J. H. Yu, J. C. Zee, M. A. Kirigiti, and M. A. Ibanez for expert technical assistance, and C. Houser for preparation of this manuscript.

Correspondence should be addressed to G. B. Gu, Division of Neuroscience, Oregon Regional Primate Research Center, 505 N.W. 185th Avenue, Beaverton, OR 97006.

Copyright (C) 1999 Society for Neuroscience $\quad 0270-6474 / 99 / 193213-10 \$ 05.00 / 0$ organ of the lamina terminalis (OVLT) region ( $\mathrm{Gu}$ and Simerly, 1997), which project to the median eminence and are thought to participate in the initiation of the LH surge. However, it remains unclear how AVPV neurons exert their stimulatory effects on the activity of GnRH cells.

A variety of neurotransmitters have been implicated in the regulation of the LH surge, and recent studies suggest that the activation of receptors for glutamate plays a critical role in the initiation of the steroid-induced LH surge that occurs during puberty and in adult animals. In immature and adult ovariectomized rats, the estrogen-induced LH surge can be blocked by administration of an NMDA receptor antagonist or antagonists of both NMDA and non-NMDA receptors (Lopez et al., 1990; Urbanski and Ojeda, 1990). NMDA and non-NMDA antagonists can also block the progesterone-induced LH surge in estrogenprimed ovariectomized immature and adult rats (Brann and Mahesh, 1991a,b; Ping et al., 1994a). On the other hand, the facilitatory effects of the activation of AMPA and NMDA receptors appear to be dependent on estrogen (Arias et al., 1993; Brann, 1995; Ping et al., 1995). At least some of these effects occur at the level of the preoptic region because excitatory amino acids (EAAs) stimulate GnRH release from preoptic tissue fragments in vitro (Bourguignon et al., 1989), and injection of EAAs into the preoptic region stimulates LH release (Ondo et al., 1988). Therefore, glutamate receptors appear to represent essential components in the neural transduction of hormonal positive feedback on gonadotropin secretion. Moreover, sex steroid hormones may regulate the expression or responsiveness of glutamate receptors in key neural pathways or may alter glutamate release, thereby influencing the expression and/or secretion of GnRH. To test this 
idea, we used immunocytochemistry and in situ hybridization to determine which subunits of glutamate receptors are expressed and hormonally regulated in the AVPV of female rats.

\section{MATERIALS AND METHODS}

Animals and treatments. The protocols used here were approved by the Oregon Regional Primate Research Center Institutional Committee for the Care and Use of Animals in Research and Education, in accordance with the guidelines of the National Institute of Health and United States Department of Agriculture. Juvenile female Sprague Dawley rats were obtained from B \& K Universal Inc. (Kent, WA) and housed on a 14:10 light/dark schedule with light on at 5:00 A.M. Food and water were available ad libitum. Juvenile female Sprague Dawley rats were ovariectomized bilaterally on day 22 of life and implanted subcutaneously with a silastic capsule containing $17 \beta$-estradiol (E2) $(400 \mu \mathrm{g} / \mathrm{ml}$ dissolved in corn oil; tubing internal diameter, $1 \mathrm{~mm}$; outer diameter, $2.16 \mathrm{~mm} ; 20$ $\mathrm{mm}$ in length/100 gm body weight; Sigma, St. Louis, MO) $[n=12$ (4 for immunocytochemistry, 4 for in situ hybridization, and 4 for double in situ hybridization)] or control capsules (oil only) $[n=12$ (4 for immunocytochemistry, 4 for in situ hybridization, and 4 for double in situ hybridization)] $5 \mathrm{~d}$ later. This dosage of E2 has been confirmed to reliably reproduce the preovulatory levels of plasma E2 measured during the initiation of puberty in the rat (Andrews et al., 1981). Forty-eight hours after implantation, paired groups of animals (treated with E2 or control capsules) were killed by transcardial perfusion. In addition, to simulate the sequence of events observed during the afternoon of the first proestrus, a time during which elevated E2 levels are accompanied by a marked and abrupt increase in progesterone levels (Parker and Mahesh, 1976; Andrews et al., 1980), four groups of animals $(n=4$ for each group) were ovariectomized and treated with E2 (see above) for $48 \mathrm{hr}$ and then injected subcutaneously with progesterone at 12:00 P.M. (1 $\mathrm{mg} / \mathrm{animal}$; Sigma) or corn oil and perfused 3 or $24 \mathrm{hr}$ after injection. This dosage of progesterone can markedly increase GnRH mRNA levels in estrogen-primed immature rats (Kim et al., 1989; Ma et al., 1992) but not in animals without pretreatment with estrogen (Ma et al., 1992). Two time points ( 3 and $24 \mathrm{hr}$ ) were evaluated to compare the short- and long-term effects of progesterone on the expression of glutamate receptors, which are thought to correspond to the positive and negative feedback effects of progesterone (Barraclough et al., 1986).

Tissue preparation and immunocytochemistry. Animals were deeply anesthetized with tribromoethanol (Aldrich, Milwaukee, WI), and a 1-2 $\mathrm{ml}$ blood sample was taken from the right atrium of the heart immediately before perfusion for steroid analysis. After a brief rinse with normal saline $(50-100 \mathrm{ml})$, each rat was perfused transcardially with ice-cold 4\% paraformaldehyde (Electron Microscopy Sciences, Fort Washington, PA) in $0.1 \mathrm{~m}$ borate buffer at $\mathrm{pH} 9.5$ for $20 \mathrm{~min}$. The brains were quickly removed, post-fixed for $2 \mathrm{hr}$ in the same fixative containing $20 \%$ sucrose, and then placed in $20 \%$ sucrose in $0.02 \mathrm{M}$ potassium PBS (KPBS) for cryoprotection. Thirty-micrometer-thick frozen sections through the AVPV of each brain were collected, at a frequency of one of four, in chilled $0.02 \mathrm{M}$ KPBS. Free-floating sections were incubated in anti-GluR1, anti-GluR2/3, GluR4 (raised in rabbit; Chemicon, Temecula, CA), GluR5/6/7 (mouse monoclonal antibody; PharMingen, San Diego, CA), and anti-NMDAR1 primary antisera (raised in rabbit; Chemicon) at $4^{\circ} \mathrm{C}$ with constant agitation for $72 \mathrm{hr}$. The GluR1, GluR2/3, and GluR4 antibodies were generated from a C-terminus peptide of rat GluR1, GluR2, and GluR4, respectively. GluR5/6/7 antibody was prepared against a fusion protein from the $\mathrm{N}$-terminal putative extracellular portion of GluR5, which belongs to the kainate type of glutamate receptor, and affinity purified using the immunogen peptide (Wenthold et al., 1992; Huntley et al., 1993). The anti-GluR1 recognizes GluR1, the anti-GluR2/3 recognizes GluR2 and GluR3, the anti-GluR4 recognizes GluR4, and the anti-GluR5/6/7 recognizes GluR5, GluR6, and GluR7 but not other members of the GluR family. The NMDAR1 antibody was generated from a synthetic peptide corresponding to the $\mathrm{C}$ terminus of rat NMDAR1 subunit and affinity purified using the immunogen peptide. Selective for splice variants NMDAR1-1a, NMDAR1-1b, NMDAR1-2a, and NMDAR1-2b, this antibody is specific for NMDAR1 and does not appear to cross-react with other glutamate receptor subunits (Petralia et al., 1994). The GluR1, GluR2/3, GluR4, GluR5/6/7, and NMDAR1 antibodies were diluted to 1:4000, 1:2000, 1:1000, 1:2000, and 1:500, respectively, in KPBS that contained $2 \%$ normal goat serum (Colorado Serum Co.) and 0.3\% Triton X-100 (Bio-Rad, Hercules, CA). After brief rinses in KPBS containing $0.3 \%$ Triton X-100, the sections were then incubated in a biotinylated goat anti-rabbit IgG secondary antiserum (Vector Laboratories, Burlingame, CA) at room temperature. The sections were rinsed in KPBS and stained by using the ABC method (Hsu et al., 1981) with commercial reagents (Elite kit; Vector Laboratories) at room temperature, and the incubations in the secondary antiserum and $\mathrm{ABC}$ solution were repeated, followed by several rinses in KPBS. The sections were then color-reacted with $0.03 \%$ diaminobenzidine (Sigma), 2.5\% nickel ammonium sulfate, 0.2\% D-glucose, $0.04 \%$ ammonium chloride, and $0.001 \%$ glucose oxidase (Sigma) in $0.1 \mathrm{M}$ acetate buffer. All sections were mounted on gelatin-coated microscopic slides, air dried, dehydrated, and coverslipped.

In situ hybridization. Twenty-micrometer-thick frozen sections (at a frequency of one of four) through the AVPV of each brain were collected in chilled 0.02 м KPBS that contained $0.25 \%$ paraformaldehyde, $\mathrm{pH} 7.4$, mounted onto gelatin-subbed, poly-L-lysine-coated microscopic slides, and processed for in situ hybridization as described previously (Simmons et al., 1989). To control for procedural artifacts, all tissue hybridized with each probe was processed together in a single in situ hybridization histochemistry experiment. After a 30 min proteinase $\mathrm{K}$ digestion (10 $\mu \mathrm{g} / \mathrm{ml}$ at $37^{\circ} \mathrm{C}$; Boehringer Mannheim, Indianapolis, IN) and acetylation $(0.0025 \%$ acetic anhydride at room temperature), the sections were dehydrated in ascending alcohols and dried under vacuum overnight. T7 polymerase (Promega, Madison, WI) was used to transcribe ${ }^{35}$ S-labeled antisense cRNA probes from a 721 bp PstI fragment of plasmid pBluescript SK $(-)$ complementary to the $5^{\prime}$ coding region of rat glutamate receptor subunit gene GluR1, from a 428 bp SphI fragment complementary to the $5^{\prime}$ coding region of rat glutamate receptor subunit gene GluR2, or from a 723-bp SarI fragment, which is complementary to the 5 ' coding region of rat glutamate receptor subunit gene GluR3 (all three probes were kindly provided by Dr. S. Heinemann, The Salk Institute, La Jolla, CA). For the NMDAR1 probe, T3 polymerase (Promega) was used to transcribe a ${ }^{35} \mathrm{~S}$-labeled antisense cRNA probe from an $868 \mathrm{bp}$ cDNA insert corresponding to nucleotides $699-1567$ of the rat NMDAR1 gene sequence (Moriyoshi et al., 1991) contained in a pBluescript SK(-) transcription vector (Urbanski et al., 1994). T3 or T7 polymerase was also used to transcribe ${ }^{35} \mathrm{~S}$-labeled antisense cRNA probes from cDNA inserts corresponding to metabotropic glutamate receptor (mGluR) subtypes: mGluR1 (nucleotides 3541-4282), mGluR2 (nucleotides 2712-3294), mGluR3 (nucleotides 2376-3215), mGluR4 (nucleotides 2910-3704), mGluR5 (nucleotides 1246-1786), and mGluR6 (nucleotides 3669-4418). The mGluR plasmids were generously provided by Dr. S. Nakanishi (Kyoto University, Kyoto, Japan), and mGluR 5 subclone was provided by Drs. Y. J. Ma and S. Ojeda (Oregon Regional Primate Research Center). The radiolabeled cRNA probe was purified by passing the transcription reaction solution over a Sephadex G-50 Nick column (Pharmacia, Piscataway, NJ), and four $100 \mu \mathrm{l}$ fractions were collected and counted by using a scintillation counter (Packard, Meridian, CT). The leading fraction was heated at $65^{\circ} \mathrm{C}$ for $5 \mathrm{~min}$ with $500 \mu \mathrm{g} / \mathrm{ml}$ yeast tRNA (Sigma) and $50 \mu \mathrm{M}$ dithiothreitol (DTT) (Stratagene, La Jolla, CA) in DEPC (Sigma) water and then diluted to an activity of $5 \times 10^{6}$ with hybridization buffer containing 50\% formamide (Boehringer Mannheim), $0.25 \mathrm{M}$ sodium chloride, $1 \times$ Denhardt's solution (Sigma), and $10 \%$ dextran sulfate (Pharmacia). This hybridization solution was pipetted onto the sections $(80 \mu \mathrm{l} /$ slide), which were covered with a glass coverslip, and sealed with DPX (Electron Microscopy Sciences) before incubation for $20 \mathrm{hr}$ at $58^{\circ} \mathrm{C}$. After hybridization, the slides were washed four times (5 min each) in $4 \times \mathrm{SSC}$ before RNase digestion $(20 \mu \mathrm{g} / \mathrm{ml}$ for $30 \mathrm{~min}$ at $37^{\circ} \mathrm{C}$; Sigma) and rinsed at room temperature in decreasing concentrations of SSC that contained $1 \mathrm{~mm}$ DTT $(2 \times, 1 \times, 0.5 \times$ for $10 \mathrm{~min}$ each $)$ to final stringency of $0.1 \times \mathrm{SSC}$ at $65^{\circ} \mathrm{C}$ for $30 \mathrm{~min}$. After dehydration in ascending alcohols, the sections were exposed to DuPont (Billerica, MA) Cronex x-ray films for 4 and $8 \mathrm{~d}$, together with autoradiographic ${ }^{14} \mathrm{C}$ microscales (Amersham, Arlington Heights, IL), before being dipped in NBT-2 liquid emulsion (Eastman Kodak, Rochester, NY). The dipped autoradiograms were developed 21 d later with Kodak D-19 developer, and the sections were counterstained with thionin through the emulsion.

Double in situ hybridization. The method used in this study was a modification of that reported by Springer et al. (1991) and described in detail previously (Simerly et al., 1996). Briefly, in vitro transcription of the GluR1 insert was performed as described above, except that $1 \mu \mathrm{l}$ of a 2 $\mathrm{mM}$ solution of digoxigenin-labeled UTP (Boehringer Mannheim) was substituted for the isotope ${ }^{35}$ S-labeled UTP (DuPont NEN, Boston, MA). After incubation with T7 polymerase, the reaction mixture was treated with DNase (Promega) and RNAsin (Promega) and stabilized with EDTA (Sigma) and salt, and the total volume was adjusted to $100 \mu \mathrm{l}$ 
with 20 mM DTT. The cRNA probe was then precipitated with ethanol, dried, and resuspended in $100 \mu \mathrm{l}$ of DEPC-treated water. A total of 150 $\mu \mathrm{l}$ of digoxigenin-labeled cRNA probe was diluted in $1 \mathrm{ml}$ of hybridization solution containing ${ }^{35} \mathrm{~S}$-labeled GluR2 probe as prepared above. Prehybridization, hybridization, and posthybridization procedures were basically identical to those described above, except that the sections were not dehydrated and dried after the last $0.1 \times$ SSC rinse but were processed for further localization of digoxigenin-labeled hybrids. Before immunohistochemical detection of digoxigenin-labeled hybrids, the slides were incubated overnight in $2 \times$ SSC containing $0.05 \%$ Triton $\mathrm{X}-100$ and $2 \%$ normal goat serum at room temperature. The next day, the slides were incubated in a 1:1000 dilution of the anti-digoxigenin-alkaline phosphatase conjugate (Boehringer Mannheim) for $5 \mathrm{hr}$ at room temperature, rinsed, and then incubated overnight at room temperature in the chromogen solution, and the staining reaction was stopped by placing the slides in $10 \mathrm{~mm}$ Tris- $\mathrm{HCl}$ with EDTA. The sections were further dehydrated in ethanol (containing SSC and DTT), dried under vacuum for $30 \mathrm{~min}$, and exposed to DuPont Cronex x-ray film for $4 \mathrm{~d}$ before being dipped in Ilford K5 emulsion (Polysciences, Warrington, PA) for autoradiography to detect ${ }^{35} \mathrm{~S}$-labeled hybrids. After a 3 week exposure, the emulsion-coated slides were developed as described above, washed, dehydrated in ethanol, dried under vacuum for $30 \mathrm{~min}$, coverslipped with DPX, and evaluated at a high magnification (400×).

Quantification and analysis. The optical density of the autoradiographic images of GluR1, GluR2, GluR3, and NMDAR1 mRNAs on $\mathrm{x}$-ray films was measured by using a Macintosh-based image analysis system and NIH Image software from National Institutes of Health. Each film was illuminated with a ChromaPro 45 light source, which provided even illumination, and the image was obtained with a DageMTI (Michigan City, IN) 70 series video camera equipped with a Newvicon tube. The optical density of autoradiographic images over the AVPV ( $4 \mathrm{~d}$ exposure) was measured on film at the same level from each brain. The boundaries of the AVPV were determined from observation of the corresponding Nissl-stained sections. A total of eight frames of images were averaged, and the film densities were integrated over the entire AVPV. The mean optical density over a large irregularly shaped region over the third ventricle adjacent to the AVPV that did not contain specific hybridization signals was also measured on each section and used to calculate the mean background density, which was subtracted from the optical density measurement of signals over the AVPV. Although these mean optical density measurements do not correspond to absolute optical density units, they reflect relative mRNA levels in the AVPV. Commercially available ${ }^{14} \mathrm{C}$ autoradiographic standards were exposed to each $\mathrm{x}$-ray film along with the experimental material. The mean optical density of an interactively defined region over each standard was measured; these measurements confirmed the linearity of the responsiveness of the film, as well as the consistency of signal detection across films. The mean optical densities of the autoradiographic images recorded over the AVPV all fell within the linear range of the standard values. Ratios between levels of GluR1/GluR2 mRNA were calculated by dividing the optical density of GluR1 mRNA by the optical density of GluR2 mRNA measured for adjacent sections from the same animal. Similarly, GluR3/ GluR2 mRNA ratios were also calculated. A two-way ANOVA was used to test for significant differences in densities of GluR1-3 or NMDAR1 mRNAs among groups in each experiment, and a post hoc Fisher's test was used to identify significant differences between individual groups. $p \leq 0.05$ was defined as significant. The colocalization of GluR1 and GluR 2 mRNA was analyzed by counting, at a magnification of $400 \times$, the number of darkly stained digoxigenin-labeled GluR1 mRNA-containing neurons, the number of GluR2 mRNA-containing neurons, visualized by clusters of silver grains at a density of three times greater than that of background, and the number of double-labeled cells contained within the morphological borders of the AVPV.

Ultrastructural analysis. To confirm that NMDAR1 immunoreactivity was located in terminals that synapse onto AVPV neurons, sections were prepared for electron microscopic analysis. Two ovariectomized juvenile female rats that had been treated for $48 \mathrm{hr}$ with estradiol as described above were deeply anesthetized with tribromoethanol (Aldrich) and perfused transcardially with $100 \mathrm{ml}$ of normal saline, followed by $300 \mathrm{ml}$ of ice-cold fixative containing $4 \%$ paraformaldehyde, $15 \%$ picric acid, and $0.08 \%$ glutaraldehyde in $0.1 \mathrm{M}$ phosphate buffer (PB), $\mathrm{pH} 7.4$, for 20 min. The brains were quickly removed, post-fixed for $2 \mathrm{hr}$ in the same fixative without glutaraldehyde, and then rinsed in PB. Fifty-micrometerthick vibratome sections through the AVPV were collected in PB, transferred for $20 \mathrm{~min}$ in $\mathrm{PB}$ containing 10\% sucrose for cryoprotection, rapidly frozen by immersion in liquid nitrogen, and thawed at room temperature. After several rinses in $\mathrm{PB}$, they were further incubated for $10 \mathrm{~min}$ in $1 \%$ sodium borohydride (Sigma) in PB to eliminate unbound aldehydes and thoroughly washed in $\mathrm{PB}$. The sections were incubated for $72 \mathrm{hr}$ at $4^{\circ} \mathrm{C}$ under agitation in a rabbit anti-NMDAR1 antiserum (Chemicon), diluted to 1:500 in PB containing 2\% normal goat serum. After several washes, sections were transferred to a biotinylated goat anti-rabbit $\operatorname{IgG}$ secondary antiserum (Vector Laboratories) for $2 \mathrm{hr}$ at room temperature, rinsed in $\mathrm{PB}$, and incubated in $\mathrm{ABC}$ solution (Elite kit; Vector Laboratories) for $2 \mathrm{hr}$ at room temperature. The tissue-bound peroxidase was visualized by a DAB reaction $(10 \mathrm{mg}$ DAB and $5 \mu \mathrm{l}$ of hydrogen peroxide in $30 \mathrm{ml} \mathrm{PB}$ ). After extensive washes, sections were osmicated in $1 \%$ osmium tetroxide in PB for 15 min, rinsed, dehydrated in an ascending gradient of alcohols and in propylene oxide, and left for $2 \mathrm{hr}$ in propylene oxide/araldite (1:1). The tissue was polymerized in araldite for $48 \mathrm{hr}$ at $60^{\circ} \mathrm{C}$, and ultrathin sections were cut on a Reichert ultratome and examined under a Jeol-1200 EX (Peabody, MA) electron microscope.

Hormone assays. Blood samples that were taken immediately before perfusion were collected in Eppendorf tubes, left standing for coagulation at room temperature for $2 \mathrm{hr}$, and stored at $4^{\circ} \mathrm{C}$ for $24 \mathrm{hr}$. Serum was separated by centrifugation and stored at $-20^{\circ} \mathrm{C}$ until assayed for $\mathrm{E} 2$ and progesterone by RIA as described previously (Resko et al., 1975; Hess et al., 1981). All the samples in each experiment were run in a single assay, with an intra-assay variation of $<8 \%$, and the lower limits of detection were $5 \mathrm{pg} /$ tube in the estrogen assay, $<3.2 \%$ intra-assay variation, and 12 $\mathrm{pg} /$ tube lower limits of detection in the progesterone assay.

\section{RESULTS}

\section{Distribution of glutamate receptors in the AVPV}

Each part of the preoptic region contained neurons that were immunoreactive for ionotropic GluR1-3 receptor subunits; however, each subtype showed a unique distribution. GluR1immunoreactive cell bodies and fibers were particularly dense in the AVPV, relative to the significantly lower levels of staining in surrounding areas (Fig. $1 A$ ). Moreover, the intensity of GluR1 immunostaining in the AVPV was noticeably greater in fibers than in cell bodies. The density of GluR2/3-immunoreactive neurons in the AVPV was much lower than that of GluR1immunoreactive cells and appeared to be clustered in the medial part of the nucleus (Fig. 1B). A similar density of GluR2/3 neurons were localized to the median preoptic and periventricular preoptic nuclei. In contrast with GluR1 immunoreactivity, GluR2/3 staining in the AVPV was primarily found in neuronal cell bodies, with only a low density of labeled fibers present. AVPV neurons do not appear to express detectable levels of GluR4 immunoreactivity, and only a few GluR4-immunoreactive fibers were observed within the borders of the nucleus (Fig. 1C). Furthermore, we found no evidence of GluR5/6/7 immunoreactivity in the AVPV. However, the majority of AVPV neurons appear to express NMDAR1 immunoreactivity (Fig. 1D). The AVPV also contains a moderately dense plexus of NMDAR1immunoreactive fibers, which have a fine and rather punctate morphology. Ultrastructural examination of these NMDAR1immunoreactive fibers confirmed that staining was contained in axon terminals, which synapse with dendritic processes and soma of AVPV neurons (Fig. $2 A, B$ ); some of these AVPV neurons were also NMDAR1-immunoreactive. In situ hybridization was used to determine whether specific mRNAs corresponding to metabotropic glutamate receptor subunits are expressed in the AVPV. No mGluR1-6 mRNA-containing neurons were found in the AVPV, although labeled mGluR2 and mGluR5 neurons were 

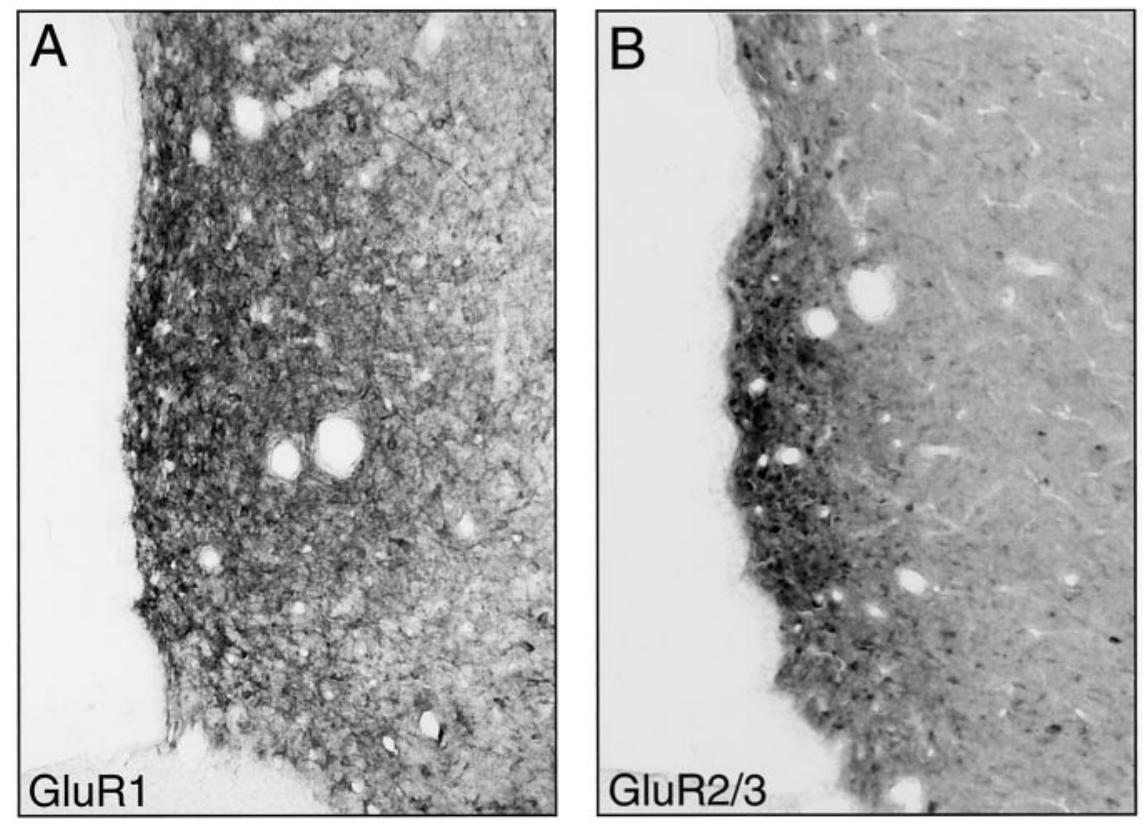

Figure 1. Distribution of GluR1 $(A)$, GluR2/3 $(B)$, GluR4 $(C)$, and NMDAR1 $(D)$ immunoreactivity in the AVPV of juvenile female rats. V3, Third ventricle. Scale bar, $50 \mu \mathrm{m}$.
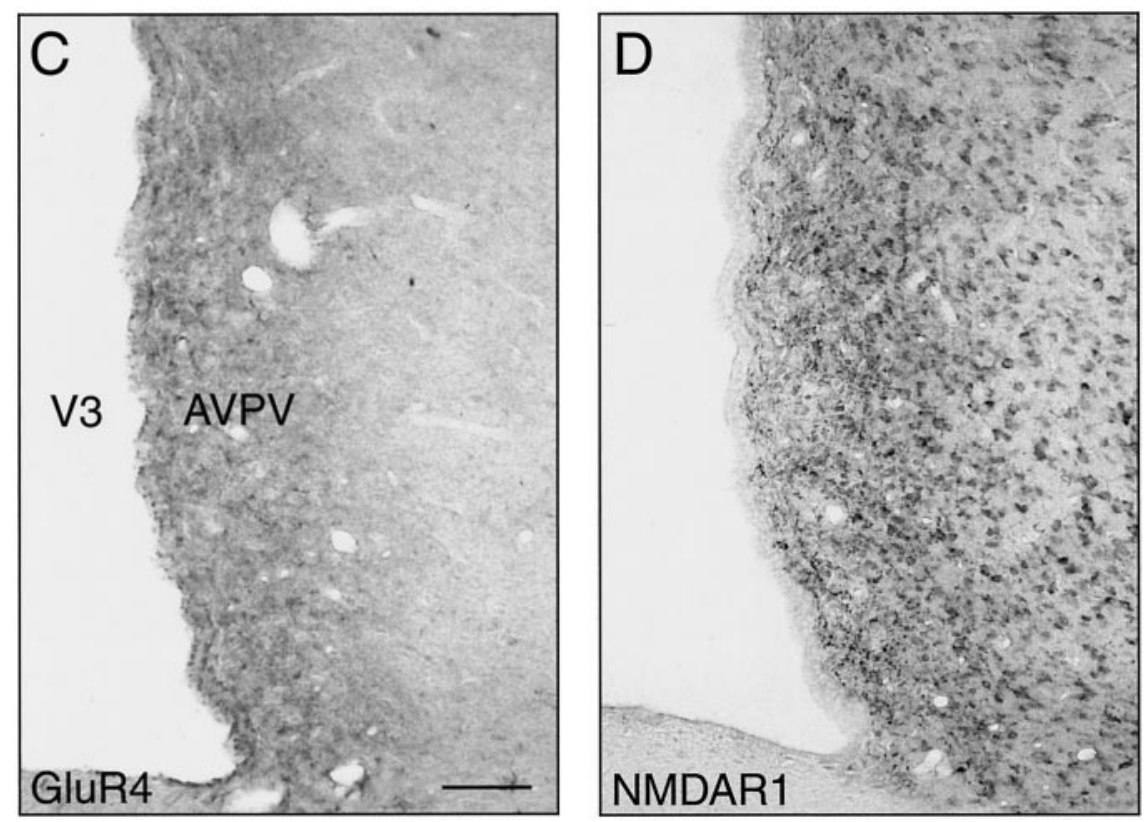

detected in neighboring regions, such as the median preoptic nucleus.

\section{Hormonal regulation of GluR1, GluR2, GluR3, and NMDAR1 gene expression in the AVPV}

Regulation by estrogen

In general, the densities of GluR1-, GluR2-, GluR3-, and NMDAR1 mRNA- containing neurons in the AVPV appear to be higher compared with the corresponding densities of immunoreactive neurons. This discrepancy may be attributable to the limited sensitivity of the immunocytochemical staining or a high turnover rate of the corresponding proteins. Treatment of ovariectomized juvenile female rats with E2 resulted in elevated levels of serum E2 $(68.5 \pm 8.5 \mathrm{pg} / \mathrm{ml}$; baseline value, $28.5 \pm 6.2)$ within the physiological range, consistent with previous reports (Andrews et al., 1981). Forty-eight hours after E2 treatment, levels of GluR1 mRNA hybridization were increased in the AVPV by over
$35 \%$ compared with those of ovariectomized animals treated with control capsules (Figs. 3, 4A,B). Similarly, estradiol treatment caused a $50 \%$ increase in the ratio of GluR1/GluR2 mRNA (Fig. 3). However, no significant differences (two-way ANOVA) in levels of GluR2 and GluR3 mRNAs (Fig. 5) or in the ratio of GluR3/GluR2 mRNA were identified between experimental and control groups. In contrast with GluR1 mRNA regulation, estradiol appears to suppress NMDAR1 mRNA levels by $\sim 50 \%$ in the AVPV (Figs. $4 C, D, 6$ ).

\section{Regulation by progesterone}

Treatment of E2-primed ovariectomized juvenile female rats with progesterone resulted in a marked increase in serum progesterone $(32.5 \pm 3.2 \mathrm{ng} / \mathrm{ml}$; baseline value, $6.7 \pm 0.9)$ by $3 \mathrm{hr}$ after injection. Progesterone levels returned to baseline by $24 \mathrm{hr}$ after injection. GluR1 mRNA levels in the AVPV were increased by 

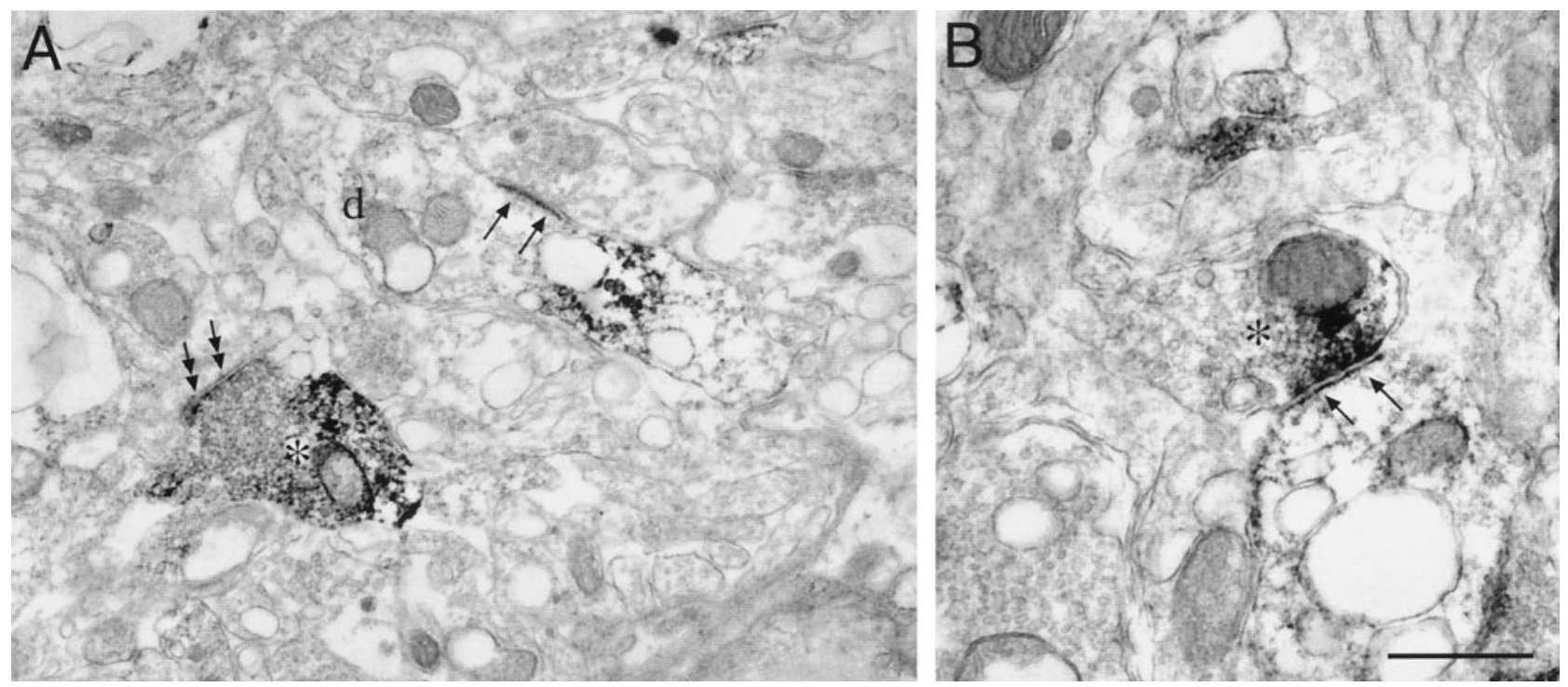

Figure 2. Subcellular localization of NMDAR1 immunostaining in the AVPV. At the ultrastructural level, NMDAR1 immunoreactivity is observed in axonal terminals (asterisks) synapsing on unlabeled dendritic processes $(A$, double arrowheads) or on NMDAR1-immunoreactive dendrites $(B$, arrows). Postsynaptic NMDAR1-immunoreactive elements, such as the dendrite $(d)$ in $A$, were frequently observed receiving an asymmetric synapse $(A$, arrows) from unlabeled terminals. Scale bar, $0.5 \mu \mathrm{m}$.

A

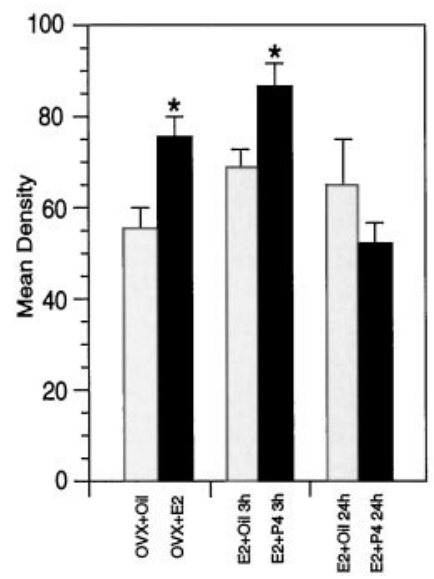

B

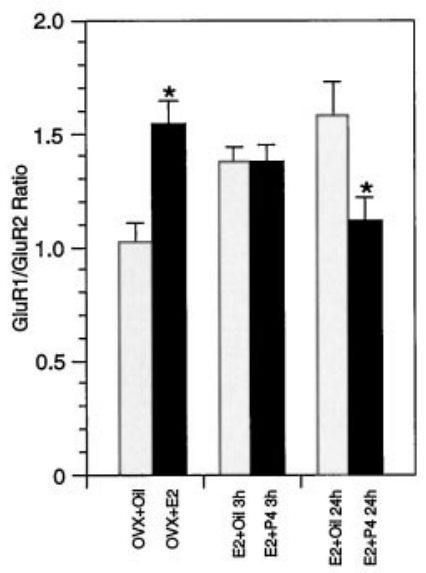

Figure 3. Comparison of hybridization signals for GluR1 $(A)$ and GluR1/GluR2 $(B)$ mRNA ratios in the AVPV of experimental and control groups of juvenile female rats. The ratio of GluR1/GluR2 mRNA was calculated by dividing the optical density of GluR1 mRNA by the optical density of GluR2 mRNA in adjacent sections from the same animal. Bars represent the mean \pm SEM density (minus background) of autoradiographic signals over the $\operatorname{AVPV}(A)$ or mean ratios $(B)$ for each experimental group. ${ }^{*} p<0.05$, significant differences between parallel experimental and control groups. E2, Estradiol; $O V X$, ovariectomy; P4, progesterone.

over $26 \%$ in rats killed $3 \mathrm{hr}$ after progesterone injection and returned to baseline by $24 \mathrm{hr}$ (Fig. 3). However, progesterone did not appear to cause significant changes in levels of GluR2 or GluR3 mRNAs in the AVPV (Fig. 5). Surprisingly, short-term progesterone treatment did not significantly alter the ratio of GluR1/GluR2 mRNA (Fig. 3) nor the GluR3/GluR2 mRNA ratio. Longer exposure to progesterone did cause a decrease in the GluR1/GluR2 mRNA ratio by $24 \mathrm{hr}$ (Fig. 3). Neither shortterm nor $24 \mathrm{hr}$ exposure to progesterone affected overall levels of NMDAR1 mRNA in the AVPV (Fig. 6).

\section{Coexpression of GluR1 and GluR2 mRNAs in the AVPV}

Double in situ hybridization was used to examine coexpression of GluR1 and GluR2 in the AVPV. The degree of colocalization suggests that nearly all of the GluR2 mRNA-containing neurons also express GluR1 mRNA (Fig. 7). However, only $85 \%$ of the GluR1 mRNA-containing neurons were found to contain detectable levels of GluR2 mRNA. Although E2 treatment clearly induces expression of GluR1 mRNA, it did not appear to influence the percentage of colocalization or alter the number of GluR1 mRNA-containing neurons in the AVPV.

\section{DISCUSSION}

The results of our analysis of glutamate receptor expression in the AVPV indicate that a somewhat restricted complement of receptor subtypes is expressed by these neurons. No evidence for expression of metabotropic receptors (mGluR1-6) was obtained. AMPA and NMDA receptors appear to be expressed in the greatest abundance with GluR1 mRNAs being present in the highest levels. The AVPV occupies an important position in neuroendocrine neural circuits (Simerly, 1997) and may represent a particularly important site for interactions between sex steroid hormones and EAAs because it contains a high density of AMPA and NMDA receptors and contains an abundance of neurons that express ovarian steroid hormone receptors. Thus, the hormonal regulation of glutamate receptor expression demonstrated in this study may contribute to the positive feedback of ovarian steroids on gonadotropin secretion. Previous studies have shown that both sex steroids and glutamate receptors are essential for the LH surge (for review, see Brann, 1995). However, few of the GnRH neurons that project to the median eminence appear to express glutamate receptors (Abbud and Smith, 1995; Urbanski et al., 1996), suggesting that an indirect mechanism may be involved in the induction of an $\mathrm{LH}$ surge by excitatory amino acids.

Both EAAs and E2 can promote gonadotropin secretion through the activation of GnRH neurons in vivo (for review, see Brann, 1995; Urbanski et al., 1996). These effects may be attributable to interactions between sex steroids and EAA-containing 

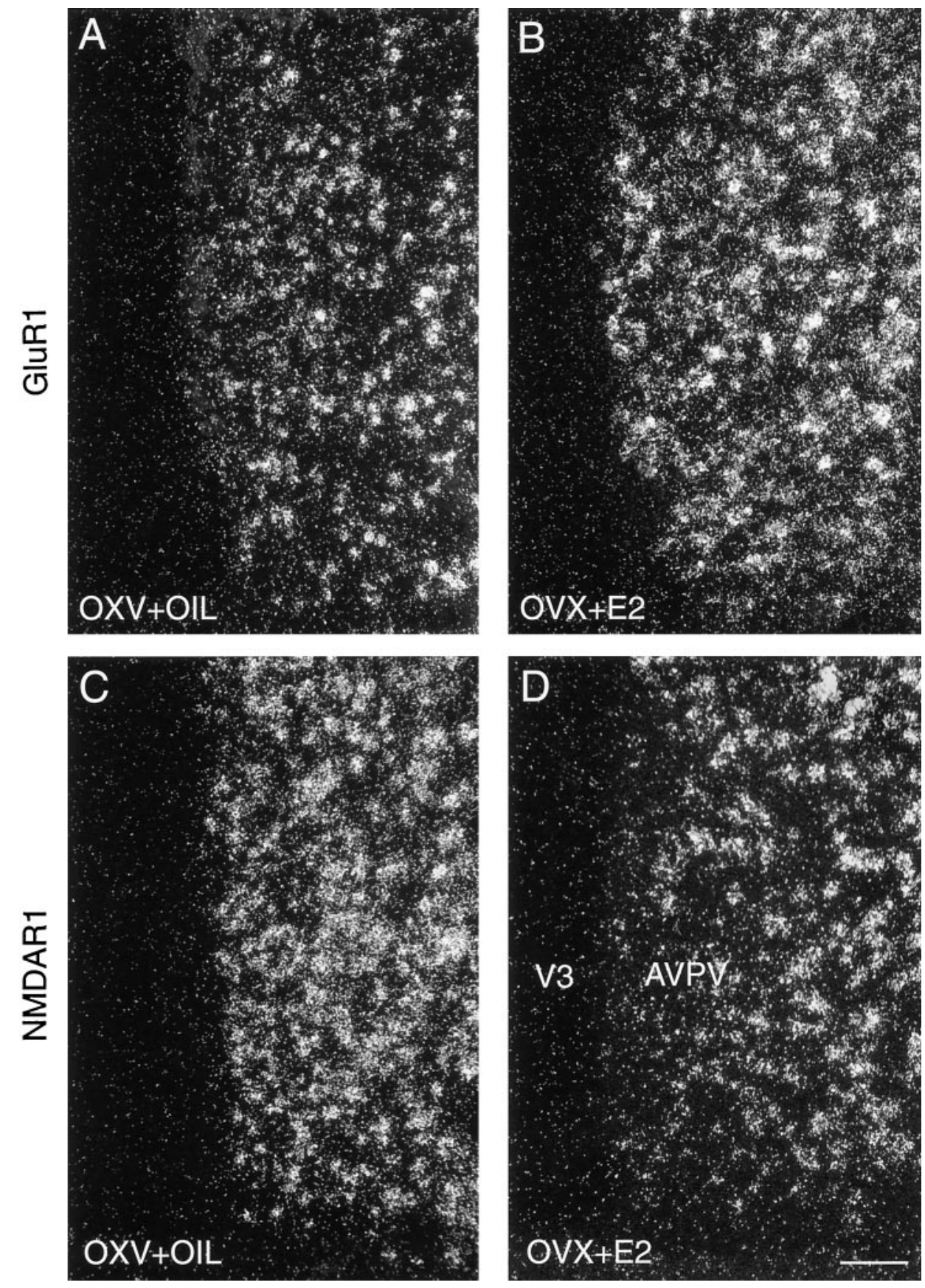

Figure 4. Photomicrographs that illustrate the effects of E2 on expression of GluR1 ( $A$, $B)$ and NMDAR1 $(C, D)$ mRNA in the AVPV neurons of juvenile female rats. V3, Third ventricle. Scale bar, $50 \mu \mathrm{m}$.

neural pathways because pharmacological blockade of either steroid hormones or EAA receptors abolishes their effects on gonadotropin secretion (Estienne et al., 1990; Brann and Mahesh, 1991a,b, 1992; Reyes et al., 1991; Brann et al., 1993; Lee et al., 1993; Luderer et al., 1993; Brann, 1995). Hormonal signals may influence glutamatergic neurotransmission in the brain by regulating the expression of different ionotropic glutamate receptor subunits (Diano et al., 1997), resulting in the elaboration of receptors with different properties. Glutamate receptor subunits are expressed differentially during normal development (Pellegrini-Giampietro et al., 1991; Bahn et al., 1994; Sheng et al., 1994) and in response to environmental changes (PellegriniGiampietro et al., 1992; Pollard et al., 1993; Prince et al., 1995; Fitzgerald et al., 1996). Our results demonstrate that E2 specifically promotes the expression of GluR1 AMPA type subunits in the AVPV of juvenile rats but leaves levels of GluR2 and GluR3 unchanged. This result is consistent with that of earlier studies, which found that the expression of non-NMDA receptors (Weiland, 1992), and specifically the GluR1 subunit, is increased by treatment with E2 plus progesterone (Brann and Mahesh, 1994) or by estrogen treatment alone (Weiland, 1992; Ulibari and Akesson, 1993), and AMPA receptor binding levels in the hypothalamus were increased at the time of puberty in the female rat (Zamorano et al., 1998). Although these previous studies did not address hormonal regulation of GluR2 expression, changes in levels of GluR2 mRNA appear to occur elsewhere in the developing brain (Pellegrini-Giampietro et al., 1991).

The observed regulation of glutamate receptor expression by sex steroid hormones appears to be specific for the AVPV, because the same pattern does not occur in the lateral septal nucleus 


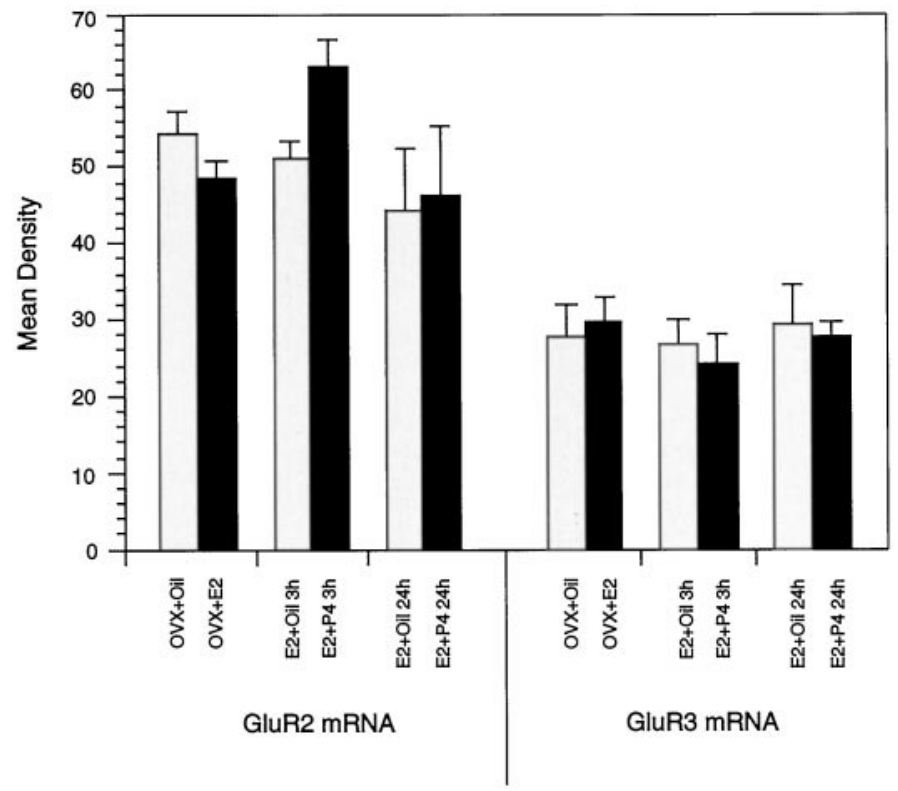

Figure 5. Comparison of hybridization signals for GluR2 and GluR3 mRNAs in the AVPV of experimental and control groups of juvenile female rats. Bars represent the mean \pm SEM density (minus background) of autoradiographic signals over the AVPV for each experimental group. There were no significant differences between parallel experimental and control groups. E2, Estradiol; $O V X$, ovariectomy; P4, progesterone.

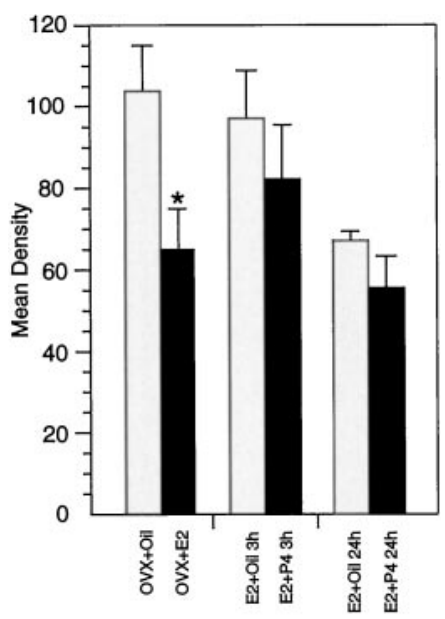

Figure 6. Hybridization signals measured for NMDAR1 mRNA level in the AVPV of experimental and control groups of juvenile female rats. Bars represent the mean \pm SEM density (minus background) of autoradiographic signals over the AVPV for each experimental group. ${ }^{*} p<$ 0.05 , significant difference between parallel experimental and control groups. E2, Estradiol; $O V X$, ovariectomy; $P 4$, progesterone.

in which estradiol appears to upregulate levels of NMDAR1 mRNA but leaves the levels of GluR1 mRNA unchanged (Varoqueaux et al., 1997).

Estrogen may potentiate glutamatergic neurotransmission in the AVPV by its induction of GluR1 expression and lack of effect on GluR2 mRNA, which leads to an increase in the GluR1/ GluR2 ratio. Ionotropic glutamate receptors are thought to have a pentameric structure (for review, see Hollmann and Heinemann, 1994), and a single neuron can express different combinations of AMPA receptor subunits (Lambolez et al., 1992). AMPA subunits may form homomeric ion channels or combine with

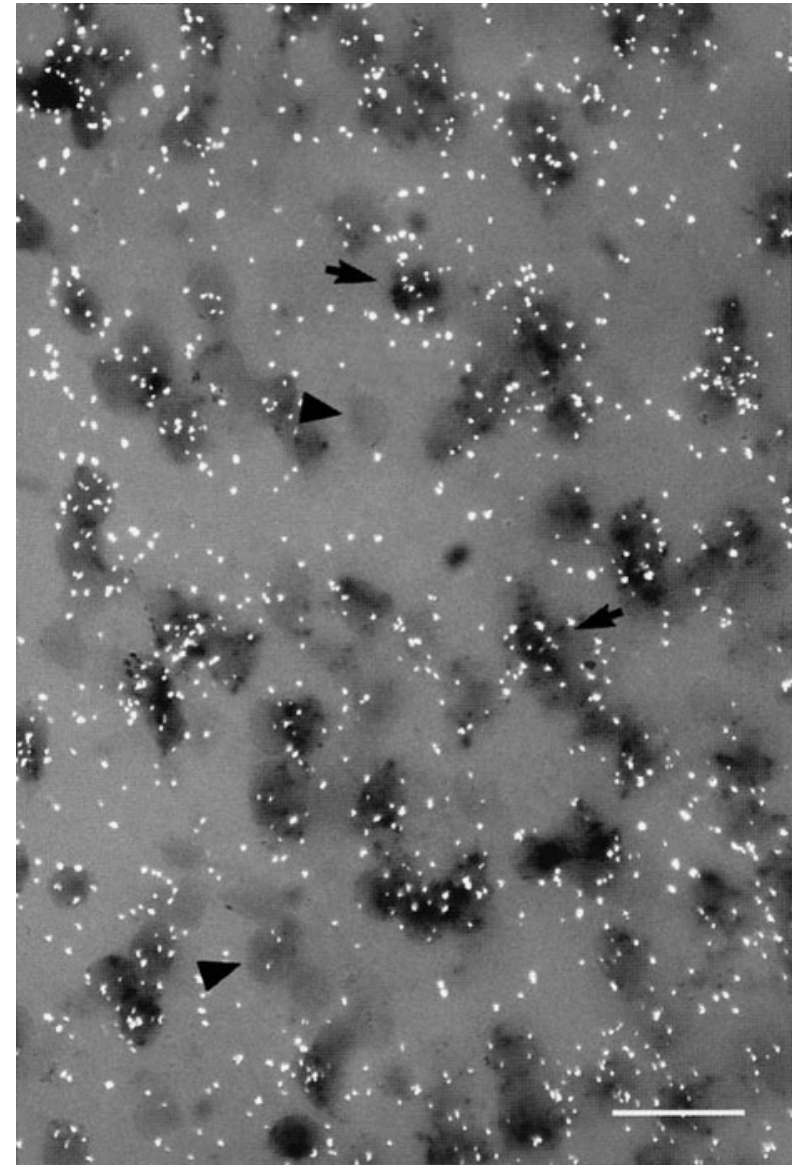

Figure 7. Combined bright-field-epi-illumination photomicrograph of GluR1 mRNA-containing neurons (dark cells) in the AVPV, visualized with a digoxigenin-labeled cRNA probe, double labeled for GluR2 mRNA (bright silver grains) by using a ${ }^{35}$ S-labeled cRNA probe. Arrows indicate double-labeled GluR1 and GluR2 mRNA-containing neurons. Arrowheads indicate single-labeled GluR1 mRNA-containing neurons. Scale bar, $20 \mu \mathrm{m}$.

other subtypes to constitute heteromeric receptors, which exhibit a wide range of functional diversity that is dependent on the complement of subunits present. A close correlation between steady-state levels of mRNAs for distinct GluR subunits and the functional properties of glutamate-activated channels has been demonstrated for other neurons (Lambolez et al., 1992; Geiger et al., 1995; Chew et al., 1997), and the high percentage of AVPV neurons that coexpress GluR1 and GluR2 subunits suggests that the majority of AMPA receptors in the AVPV may be heteromeric. In a heteromeric AMPA receptor channel, GluR2 subunits dominate the rectification properties and decrease permeability to calcium (Hollmann and Heinemann, 1994; Geiger et al., 1995). However, other AMPA subunits appear to enhance the $\mathrm{Ca}^{2+}$ permeability of individual channels. Thus, a cellular consequence of E2 positive feedback may be an increase in the calcium permeability of the ionotropic channels in AVPV neurons brought about by upregulation of the GluR1 subunits and the subsequent increase in the ratio of GluR1/GluR2. The increase in the GluR1/ GluR2 ratio effected by estrogen contrasts with the decrease in this ratio caused by progesterone $24 \mathrm{hr}$ after treatment. Although progesterone caused a significant increase in levels of GluR1 mRNA $3 \mathrm{hr}$ after treatment, there was no significant change in the GluR1/GluR2 mRNA ratio, perhaps because of a small, statisti- 
cally insignificant increase in GluR2 mRNA. However, the ratio of GluR1/GluR2 mRNA was significantly decreased by $24 \mathrm{hr}$ after treatment with progesterone. These findings indicate that E2 and progesterone may have opposing actions on the ratio of GluR1/ GluR2 gene expression, which therefore suggests they may exert opposing effects on glutamatergic neurotransmission in the AVPV. Whereas estrogen potentiates neuronal firing in the AVPV, progesterone may suppress the activity of these neurons, which may contribute to the termination of the positive feedback after the LH surge is generated.

That E2 treatment suppresses NMDAR1 mRNA in the AVPV is a surprising observation because E2, progesterone, nor testosterone affected NMDA receptor binding or mRNA levels in adult male and female rats or in juvenile female rats. This discrepancy may be attributable to differences in age, sex, or hormonal treatment models but is more likely to be because of the fact that NMDA receptor expression in the AVPV was not specifically addressed in the earlier studies. Furthermore, the presence of NMDAR1 terminals in the AVPV, as demonstrated in the present work, may render the downregulation of NMDA receptor expression in AVPV neurons less remarkable in binding studies, which cannot distinguish between presynaptic and postsynaptic receptors.

The NMDAR1 subunit is an essential part of NMDA receptors. Therefore, a decrease in its expression may reflect an overall decrease in levels of NMDA receptors in the AVPV. The results of previous studies indicate that the selective activation of AMPA receptors leads to a moderate, nontoxic elevation of intracellular free calcium (50-100\%), whereas activation of NMDA receptors results in a $300-400 \%$ increase in intracellular free calcium, which can be neurotoxic (Cheng and Mattson, 1992). Estrogen has been shown to protect neurons against excitotoxic damage (Behl et al., 1997; Simpkins et al., 1997), and downregulation of NMDA receptors may contribute to its neuroprotective action. Therefore, estrogen may enhance AMPA receptor-mediated neurotransmission in the AVPV, while at the same time preventing NMDA receptor-mediated neurotoxicity, which may be important during positive feedback before the LH surge when levels of glutamate in the preoptic area are elevated (Jarry et al., 1992; Ping et al., 1994b).

NMDA is also thought to act presynaptically, and the presence of NMDAR1 subunit in presynaptic neuronal elements has been documented (Liu et al., 1994; Farb et al., 1995; Aicher et al., 1997; Gracy et al., 1997; Van Bockstaele and Colago, 1997). NMDAR1 immunoreactivity is clearly present in presynaptic terminals in the AVPV, which terminate on both cell soma and dendrites. These subunits may form autoreceptors, as demonstrated in the spinal cord (Liu et al., 1994), and activation of these receptors may trigger a release of glutamate from these terminals. Although other studies report that progesterone increases glutamate release in the preoptic area, the precise role of presynaptic NMDA receptors in the AVPV remains unknown.

The functional significance of the differential regulation of AMPA and NMDAR1 glutamate receptor subunits in the AVPV for the neuroendocrine control of reproduction remains unexplored. It seems unlikely that $\mathrm{GnRH}$ neurons are unresponsive to glutamate, but clear evidence for direct activation is lacking. Furthermore, we did not evaluate the expression of either KA1 or KA2 subtype kainate receptor in the AVPV, and approximately one-third of GnRH neurons appear to express KA2 receptors (Eyigor and Jennes, 1997). Nevertheless, as a nodal point in neural pathways mediating hormonal control of gonadotropin secretion, the AVPV is a likely site for interactions between ovarian steroids and glutamatergic neurotransmission affecting the preovulatory LH surge. Moreover, the AVPV receives inputs from other forebrain regions that convey a variety of sensory modalities known to modulate gonadotropin secretion, including olfaction and visceral sensory information (for review, see Simerly, 1997). Thus, by altering the sensitivity of AVPV neurons to glutamatergic activation, ovarian steroids may regulate the relative impact of this sensory information on GnRH neurons, thereby coordinating reproductive responses with environmental constraints.

\section{REFERENCES}

Abbud R, Smith MS (1995) Do GnRH neurons express the gene for the NMDA receptor? Brain Res 690:117-120.

Aicher SA, Sharma S, Cheng PY, Pickel VM (1997) The N-methyl-Daspartate (NMDA) receptor is postsynaptic to substance P-containing axon terminals in the rat superficial dorsal horn. Brain Res 772:71-81.

Andrews WW, Advis JP, Ojeda SR (1980) The first proestrus in the female rat: circulating steroid levels preceding and accompanying the preovulatory LH surge. Proc Soc Exp Biol Med 163:305-309.

Andrews WW, Mizejewski GJ, Ojeda SR (1981) Development of estradiol-positive feedback on luteinizing hormone release in the female rat: a quantitative study. Endocrinology 109:1404-1413.

Arias P, Jarry H, Leonhardt S, Moguilevsky J, Wuttke W (1993) Estradiol modulates the $\mathrm{LH}$ release response to $N$-methyl-D-aspartate in adult female rats: studies on hypothalamic luteinizing hormonereleasing hormone and neurotransmitter release. Neuroendocrinology 57:710-715.

Bahn S, Volk B, Wisden W (1994) Kainate receptor gene expression in the developing rat brain. J Neurosci 14:5525-5547.

Barraclough CA, Camp P, Weiland N, Akabori A (1986) Stimulatory versus inhibitory effects of progesterone on estrogen-induced phasic $\mathrm{LH}$ and prolactin secretion correlated with estrogen nuclear and progestin cytosol receptor concentrations in brain and pituitary gland. Neuroendocrinology 42:6-14.

Behl C, Skutella T, Lezoualc'h F, Post A, Widmann M, Newton CJ, Holsboer F (1997) Neuroprotection against oxidative stress by estrogens: structure-activity relationship. Mol Pharmacol 51:535-541.

Bourguignon J, Gerard A, Mathieu J, Franchimont P (1989) Pulsatile release of gonadotropin-releasing hormone from hypothalamic explants is restrained by blockade of $N$-methyl-D,L-aspartate receptors. Endocrinology 125:1090-1096.

Brann DW (1995) Glutamate: a major excitatory transmitter in neuroendocrine regulation. Neuroendocrinology 61:213-225.

Brann DW, Mahesh VB (1991a) Endogenous excitatory amino acid involvement in the preovulatory and steroid-induced surge of gonadotropins in the female rat. Endocrinology 128:1541-1547.

Brann DW, Mahesh VB (1991b) Endogenous excitatory amino acid regulation of the progesterone-induced LH and FSH surge in estrogenprimed ovariectomized rats. Neuroendocrinology 53:107-110.

Brann DW, Mahesh VB (1992) Excitatory amino acid regulation of gonadotropin secretion: modulation by steroid hormones. J Steroid Biochem Mol Biol 41:847-850.

Brann DW, Mahesh VB (1994) Excitatory amino acids: function and significance in reproduction and neuroendocrine regulation. Front Neuroendocrinol 15:3-49.

Brann DW, Ping L, Mahesh VB (1993) Possible role of non-NMDA receptor neurotransmission in steroid-induced and preovulatory gonadotropin surges in the female rat. Mol Cell Neurosci 4:292-297.

Cheng B, Mattson MP (1992) IGF-I and IGF-II protect cultured hippocampal and septal neurons against calcium-mediated hypoglycemic damage. J Neurosci 12:1558-1566.

Chew L-J, Fleck MW, Wright P, Scherer SE, Mayer ML, Gallo V (1997) Growth factor-induced transcription of GluR1 increases functional AMPA receptor density in glial progenitor cells. J Neurosci 17:227-240.

Diano S, Naftolin F, Horvath TL (1997) Gonadal steroids target AMPA glutamate receptor-containing neurons in the rat hypothalamus, sep- 
tum and amygdala: a morphological and biochemical study. Endocrinology 138:778-789.

Estienne MJ, Schillo KK, Hileman SM, Green MA, Hayes SH (1990) Effect of $N$-methyl-D,L-aspartate on luteinizing hormone secretion in ovariectomized ewes in the absence presence of estradiol. Biol Reprod 42:126-130.

Eyigor O, Jennes L (1997) Expression of glutamate receptor subunit mRNAs in gonadotropin-releasing hormone neurons during the sexual maturation of the female rat. Neuroendocrinology 66:122-129.

Farb CR, Aoki C, Ledoux JE (1995) Differential localization of NMDA and AMPA receptor subunits in the lateral and basal nuclei of the amygdala: a light and electron microscopic study. J Comp Neurol 362:86-108.

Fitzgerald LW, Ortiz J, Hamedani AG, Nestler EJ (1996) Drugs of abuse and stress increase the expression of GluR1 and NMDAR1 glutamate receptor subunits in the rat ventral tegmental area: common adaptations among cross-desensitizing agents. J Neurosci 16:274-282.

Fox SR, Harlan RE, Shivers BD, Pfaff DW (1990) Chemical characterization of neuroendocrine targets for progesterone in the female rat brain and pituitary. Neuroendocrinology 51:276-283.

Geiger JRP, Melcher T, Koh D-S, Sakmann B, Seeburg PH, Jonas P, Monyer H (1995) Relative abundance of subunit mRNAs determines gating and $\mathrm{Ca}^{2+}$ permeability of AMPA receptors in principal neurons and interneurons in rat CNS. Neuron 15:193-204.

Gerall AA, Givon L (1992) Early androgen and age-related modifications in female rat reproduction. In: Handbook of behavioral neurobiology (Gerall AA, Moltz H, Ward IL eds), pp 313-354. New York: Plenum.

Gracy KN, Svingos AL, Pickel VM (1997) Dual ultrastructural localization of $\mu$-opioid receptors and NMDA-type glutamate receptors in the shell of the rat nucleus accumbens. J Neurosci 17:4839-4848.

Gu GB, Simerly RB (1997) Projections of the sexually dimorphic anteroventral periventricular nucleus in the female rat. J Comp Neurol 384:142-164.

Halasz B (1969) The endocrine effects of isolation of the hypothalamus from the rest of the brain. In: Frontiers in neuroendocrinology (Ganong WF, Martini L eds), pp 307-342. New York: Oxford UP.

Herbison AE (1998) Multimodal influence of estrogen upon gonadotropin-releasing hormone neurons. Endocr Rev 19:302-330.

Hess DL, Spies HG, Hendrickx AG (1981) Diurnal steroid patterns during gestation in the Rhesus macaque: onset, daily variation, and the effects of dexamethasone treatment. Biol Reprod 24:609-616.

Hollmann M, Heinemann S (1994) Cloned glutamate receptors. Annu Rev Neurosci 17:31-108.

Hsu SM, Raine L, Fanger H (1981) The use of avidin-biotin peroxidase complex $(\mathrm{ABC})$ in immunoperoxidase techniques: a comparison between ABC and unlabeled antibody (PAP) procedures. J Histochem Cytochem 29:577-580.

Huntley GW, Rogers SW, Moran T, Janssen W, Archin N, Vickers JC, Cauley K, Heinemann SF, Morrison JH (1993) Selective distribution of kainate receptor subunit immunoreactivity in monkey neocortex revealed by a monoclonal antibody that recognizes glutamate receptor subunits GluR5/6/7. J Neurosci 13:2965-2981.

Jarry H, Hirsch B, Leonhardt S, Wuttke W (1992) Amino acid neurotransmitter release in the preoptic area of rats during the positive feedback actions of estradiol on LH release. Neuroendocrinology 56:133-144.

Kim K, Lee BJ, Park Y, Cho WK (1989) Progesterone increases messenger ribonucleic acid (mRNA) encoding luteinizing hormone releasing hormone $(\mathrm{LHRH})$ level in the hypothalamus of ovariectomized estradiol-primed prepubertal rats. Mol Brain Res 6:151-158.

Köves K, Halász B (1970) Location of the neural structures triggering ovulation in the rat. Neuroendocrinology 6:180-193.

Lambolez B, Audinat E, Bochet P, Crépel F, Rossier J (1992) AMPA receptor subunits expressed by single Purkinje cells. Neuron 9:247-258.

Lee W, Abbud R, Hoffman GE, Smith MS (1993) Effects of $N$-methylD-aspartate receptor activation of cFos expression in luteinizing hormone-releasing hormone neurons in female rats. Endocrinology 133:2248-2254.

Liu I, Wang H, Sheng M, Jan LY, Jan YN, Basbaum AI (1994) Evidence for presynaptic $N$-methyl-D-aspartate autoreceptors in the spinal cord dorsal horn. Proc Natl Acad Sci USA 91:8383-8387.

Lopez F, Donoso A, Negro-Vilar A (1990) Endogenous excitatory amino acid regulates the estradiol-induced $\mathrm{LH}$ surge in ovariectomized rats. Endocrinology 126:1771-1773.

Luderer U, Strobl F, Levine J, Schwartz N (1993) Differential gonadotropin responses to $N$-methyl-D-aspartate (NMDA) in metestreous, proestrous, and ovariectomized rats. Biol Reprod 48:857-866.

Ma YJ, Junier MP, Costa ME, Ojeda SR (1992) Transforming growth factor- $\alpha$ gene expression in the hypothalamus is developmentally regulated and linked to sexual maturation. Neuron 9:657-670.

Moriyoshi K, Masu M, Ishii T, Shigemoto R, Mizuno N, Nakanishi S (1991) Molecular cloning and characterization of the glutamate receptor family. Nature 354:31-37.

Ojeda SR, Urbanski HF (1994) Puberty in the rat. In: The physiology of reproduction (Knobil E, Neill JD, eds), pp 363-409. New York: Raven.

Ondo J, Wheeler D, Dom R (1988) Hypothalamic site of action for $N$-methyl-D-aspartate (NMDA) on LH secretion. Life Sci 43:2283-2286.

Parker Jr CR, Mahesh VB (1976) Hormonal events surrounding the natural onset of puberty in female rats. Biol Reprod 14:347-353.

Pellegrini-Giampietro DE, Bennett MVL, Zukin RS (1991) Differential expression of three glutamate receptor genes in developing rat brain: an in situ hybridization study. Proc Natl Acad Sci USA 88:4157-4161.

Pellegrini-Giampietro DE, Zukin RS, Bennett MVL, Cho S, Pulsinelli WA (1992) Switch in glutamate receptor subunit gene expression in CA1 subfield of hippocampus following global ischemia in rats. Proc Natl Acad Sci USA 89:10499-10503.

Petralia RS, Yokotani N, Wenthold RJ (1994) Light and electron microscope distribution of the NMDA receptor subunit NMDAR1 in the rat nervous system using a selective anti-peptide antibody. J Neurosci 14:667-696.

Ping L, Mahesh VB, Brann DW (1994a) A physiological role for $N$-methy-D-aspartic acid and non- $N$-methyl-D-aspartic acid receptors in pulsatile gonadotropin secretion in the adult female rat. Endocrinology 135:113-118.

Ping L, Mahesh VB, Brann DW (1994b) Release of glutamate and aspartate from the preoptic area during the progesterone-induced LH surge: in vivo microdialysis studies. Neuroendocrinology 59:318-324.

Ping L, Mahesh VB, Brann DW (1995) Effect of NMDA and nonNMDA receptor antagonists on pulsatile luteinizing hormone secretion in the adult male rat. Neuroendocrinology 61:226-234.

Pollard H, Heron A, Moreau J, Ben-Ari Y, Khrestchatisky M (1993) Alterations of the GluR-B AMPA receptor subunit flip/flop expression in kainate-induced epilepsy and ischemia. Neuroscience 57:545-554.

Prince HK, Conn PJ, Blackstone CD, Huganir RL, Levey AI (1995) Downregulation of AMPM receptor subunit GluR2 in amygdaloid kindling. J Neurochem 64:462-465.

Resko JA, Ploem JG, Stadelman HC (1975) Estrogens in fetal and maternal plasma of Rhesus monkeys. Endocrinology 97:425-430.

Reyes A, Xia L, Ferin M (1991) Modulation of the effects of $N$-methylD,L-aspartate on luteinizing hormone by the ovarian steroids in the adult rhesus monkey. Neuroendocrinology 54:405-411.

Sheng M, Cummings J, Roldan LA, Jan YN, Jan LY (1994) Changing subunit composition of heteromeric NMDA receptors during development of rat cortex. Nature 368:144-147.

Shivers BD, Harlan RE, Morrell JI, Pfaff DW (1983) Absence of oestradiol concentration in cell nuclei of LHRH-immunoreactive neurons. Nature 304:345-347.

Simerly RB (1996) Sexually differentiated neural systems controlling the preovulatory release of gonadotropin. Curr Opin Endocrinol Diabetes 3:171-177.

Simerly RB (1997) Organization and regulation of sexually dimorphic neuroendocrine pathways. Behav Brain Res 92:195-203.

Simerly RB, Young BJ, Carr AM (1996) Co-expression of steroid hormone receptors in opioid peptide-containing neurons correlates with patterns of gene expression during the estrous cycle. Mol Brain Res 40:275-284.

Simmons DM, Arriza JL, Swanson SW (1989) A complete protocol for in situ hybridization of messenger RNAs in brain and other tissues with radio-labeled single-stranded RNA probes. J Histotechnol 12:169-181.

Simpkins JW, Green PS, Gridley KE (1997) A fundamental role for estrogens in cognition and neuroprotection. In: Pharmacological treatment of Alzheimer's disease: molecular and neurobiological foundations (Brioni JD, Decker MW eds), pp 503-523. New York: Wiley.

Springer JE, Robbins E, Gwag BJ, Lewis ME, Baldino FJ (1991) Nonradioactive detection of nerve growth factor receptor (NGFR) mRNA 
in rat brain using in situ hybridization histochemistry. J Histochem Cytochem 39:231-234.

Ulibari C, Akesson TR (1993) Estrogen regulates glutamate receptor subunit GluR1 mRNA levels in the hypothalamic ventromedial nucleus of the rat. Soc Neurosci Abstr 19:821.

Urbanski H, Ojeda S (1990) A role for $N$-methyl-D-aspartate (NMDA) receptors in the control of $\mathrm{LH}$ secretion and initiation of female puberty. Endocrinology 126:1774-1776.

Urbanski HF, Fahy MM, Daschel M, Meshul C (1994) N-Methyl-Daspartate receptor gene expression in the hamster hypothalamus and in immortalized luteinizing hormone-releasing hormone neurons. J Reprod Fertil 100:5-9.

Urbanski HF, Kohama SG, Garyfallou VT (1996) Mechanisms mediating the response of $\mathrm{GnRH}$ neurons to excitatory amino acids. Rev Reprod 1:173-181.

Van Bockstaele EJ, Colago EE (1997) Selective distribution of the NMDA-R1 glutamate receptor in astrocytes and presynaptic axon terminals in the nucleus locus coeruleus of the rat brain: an immunoelectron microscopic study. J Comp Neurol 369:483-496.

Varoqueaux F, Gu GB, Simerly RB (1997) Estrogen regulates NMDA receptor gene expression in the lateral septum of the juvenile female rat. Soc Neurosci Abstr 23:342.

Weiland NG (1992) Estradiol selectively regulates agonist binding sites on the $N$-methyl-D-aspartate receptor complex in the CA1 region of the hippocampus. Endocrinology 131:662-668.

Wenthold RJ, Yokotani N, Doi K, Wada K (1992) Immunochemical characterization of the non-NMDA glutamate receptor using subunitspecific antibodies-evidence for a hetero-oligomeric structure in rat brain. J Biol Chem 267:501-507.

Wiegand SJ, Terasawa E (1982) Discrete lesions reveal functional heterogeneity of suprachiasmatic structures in regulation of gonadotropin secretion in the female rat. Neuroendocrinology 34:395-404.

Zamorano PL, Mahesh VB, De Sevilla L, Brann DW (1998) Excitatory amino acid receptors and puberty. Steroids 63:268-270. 